\title{
Advance in Targeted Immunotherapy for Graft-Versus-Host Disease
}

\author{
Lingling Zhang ${ }^{1 *}$, Jianhua $\mathrm{Yu}^{2}$ and Wei Wei ${ }^{1 *}$ \\ ${ }^{1}$ Institute of Clinical Pharmacology, Anhui Medical University, Key Laboratory of Anti-Inflammatory and Immunopharmacology \\ of Education, Ministry of China, Anti-Inflammatory Immune Drugs Collaborative Innovation Center, Hefei, Anhui, China, \\ ${ }^{2}$ Division of Hematology, Department of Internal Medicine, College of Medicine, The Ohio State University, Columbus, \\ $\mathrm{OH}$, United States
}

\section{OPEN ACCESS}

Edited by: Djordje Miljkovic, Institute for Biological Research Sinisa Stankovic, Serbia

Reviewed by: Benedetto Bruno, Università degli Studi di Torino,

Italy

Ignacio Anegon, University of Nantes, France

*Correspondence: Lingling Zhang II-zhang@hotmail.com; Wei Wei

wwei@ahmu.edu.cn

Specialty section:

This article was submitted to Alloimmunity and Transplantation,

a section of the journal

Frontiers in Immunology

Received: 10 February 2018 Accepted: 01 May 2018

Published: 16 May 2018

Citation:

Zhang L, Yu J and Wei W (2018) Advance in Targeted Immunotherapy for Graft-Versus-Host Disease.

Front. Immunol. 9:1087. doi: 10.3389/fimmu.2018.01087
Graft-versus-host disease (GVHD) is a serious and deadly complication of patients, who undergo hematopoietic stem cell transplantation (HSCT). Despite prophylactic treatment with immunosuppressive agents, 20-80\% of recipients develop acute GVHD after HSCT. And the incidence rates of chronic GVHD range from 6 to $80 \%$. Standard therapeutic strategies are still lacking, although considerable advances have been gained in knowing of the predisposing factors, pathology, and diagnosis of GVHD. Targeting immune cells, such as regulatory $T$ cells, as well as tolerogenic dendritic cells or mesenchymal stromal cells (MSCs) display considerable benefit in the relief of GVHD through the deletion of alloactivated T cells. Monoclonal antibodies targeting cytokines or signaling molecules have been demonstrated to be beneficial for the prevention of GVHD. However, these remain to be verified in clinical therapy. It is also important and necessary to consider adopting individualized treatment based on GVHD subtypes, pathological mechanisms involved and stages. In the future, it is hoped that the identification of novel therapeutic targets and systematic research strategies may yield novel safe and effective approaches in clinic to improve outcomes of GVHD further. In this article, we reviewed the current advances in targeted immunotherapy for the prevention of GVHD.

Keywords: graft-versus-host disease, immunotherapy, immune inhibitors, immune cells, hematopoietic stem cell transplantation

\section{INTRODUCTION}

Hematopoietic stem cell transplantation (HSCT) is used to treat hematologic malignancies. Conditional on surviving the first 2 years after BMT, 5 years survival generally exceeds $70 \%$ (1). Graft-versus-host disease (GVHD) is a serious life-threatening complication in patients undergoing HSCT resulting from donor T lymphocytes activated by host antigen-presenting cells (APCs), and resulting in an inflammatory response and immune system disorders (2-5). GVHD includes two phases of pathological progress, namely acute GVHD (aGVHD) and chronic GVHD (cGVHD). $20-80 \%$ of recipients would develop aGVHD after allogeneic hematopoietic cell transplantation. And the incidence rates of cGVHD range from 6 to $80 \%$, depending on risk factors and diagnostic criteria used (1).

Despite considerable advances in knowing of the predisposing factors, pathophysiology, and diagnosis of aGVHD and cGVHD, a standard therapeutic strategy is still lacking (6-8). The American Society of Blood and Marrow Transplantation developed some recommendations for treatment of aGVHD. The standards of care treatments that are used now days include first-line treatment and second-line treatment. Steroid remains the mainstay of first-line treatment in grades II-IV GVHD. Standard treatment with prednisone showed an overall complete response (CR) rate of $48 \%$, while 
the percentage of steroid-refractory aGVHD (SR-aGVHD) is approximately 50\%. Criteria and indications for secondary systemic therapy of aGVHD have not been systematically defined. Secondary systemic therapy may be indicated earlier in patients who cannot tolerate high-dose glucocorticoid treatment. Agents for second-line treatment of aGVHD include immunosuppressive agents (mycophenolate mofetil, pentostatin, cyclophosphamide) and monoclonal antibodies (mAbs), and so on. The use of cyclophosphamide at high doses to prevent GVHD would reduce the cumulative 1-year incidence of cGVHD to $15 \%$ or less (9).

Apart from systemic corticosteroids, the therapies targeting immune cells and immune molecular have been applied currently to inhibit GVHD (10-15). Regulatory T cells (Tregs), tolerogenic dendritic cells (TDCs), or mesenchymal stromal cells (MSCs) display considerable benefit in the relief of GVHD through the deletion of alloactivated $\mathrm{T}$ cells. mAbs targeting cytokines or signaling molecules have been demonstrated to be potent therapeutic candidates for the prevention of GVHD. In this paper, we reviewed current advances in immunotherapy for GVHD.

\section{IMMUNE CELLS FOR THE TREATMENT OF GVHD}

Donor T cells recognize alloantigens and are activated in GVHD process. The activation of dendritic cells (DCs) plays critical roles in the initiation of GVHD. Targeting immune cells, such as Tregs, as well as TDCs or mesenchymal stromal cells (MSCs) display considerable benefit in reducing GVHD through the deletion of alloactivated $\mathrm{T}$ cells. Coating allogeneic $\mathrm{T}$ cells showed significantly improved survival rate and relief GVHD. Moreover, the coating allogeneic $\mathrm{T}$ cells did keep still the effect of graftversus-leukemia (GVL) (Table 1).

\section{Therapeutic Potential of Tregs for GVHD}

Host alloantigens are first recognized by donor $\mathrm{T}$ cells, and donor T cells become activated in GVHD process. An imbalance between Tregs and Th17 also involves in the pathological process. Tregs could suppress a wide range of cell types including B cells, T cells, APCs, and NK cells in MHC-unrestricted way. The roles for Tregs in inhibition of GVHD after HSCT have been demonstrated in both murine and human studies. As the negative regulators of immune responses to alloantigen, alloantigen-specific Tregs are critical for maintaining alloantigen-specific tolerance. Tregs strongly inhibited the division, expansion, and differentiation of donor T cells, suggesting a therapeutic potential of Tregs for GVHD. Tregs could protect from both acute and cGVHD (16). Tregs decrease the risk of allotransplant rejection through preventing autoimmune and allergic reactions $(17,18)$. Infusion of donor Tregs could prevent successfully aGVHD in mice and has shown promise in phase I clinical trials. Early Treg migration into lymphoid tissue and sustained donor Treg presence were important for GVHD prevention. Compared with control group, infusion of clinical-grade Tregs could also delay the onset of GVHD without causing any obvious toxicity or death in mice model (19) (Figure 1).

CCR8 could potentiate the survival of Tregs by promoting the interactions with DCs (20). Enforced IL-10 expression converts human $\mathrm{CD} 4^{+} \mathrm{T}$ cells into $\mathrm{T}$ regulatory type 1 -like $\left(\mathrm{CD} 4^{\mathrm{IL}-10}\right)$ cells that suppress effector $\mathrm{T}$ cells in vitro and mouse models (21). Short-lived apoptotic protein Fas ligand (FasL) increases the suppressive activity of Tregs and ameliorates GVHD severity (22). Pharmacological blockade or genetic deficiency of C3aR/ C5aR signaling could augment the generation of induced Treg (iTreg), stabilize Foxp3 expression, and resist iTreg conversion to effector $\mathrm{T}$ cells producing IFN- $\gamma / \mathrm{TNF}$-alpha, resulting in limiting GVHD (23). Natural Tregs might induce tolerance in

TABLE 1 | Immune cells and monoclonal antibodies (mAbs) to cytokines for the treatment of graft-versus-host disease (GVHDs).

\begin{tabular}{|c|c|c|c|c|}
\hline Different classes & Cells or agents & Mechanisms & Types of GVHD & Clinical translation \\
\hline \multirow[t]{5}{*}{ Immune cells } & Regulatory $T$ cells & $\begin{array}{l}\text { Suppress the functions of T cells, } \\
\text { natural killer (NK) cells, B cells, and APCs }\end{array}$ & aGVHD and cGVHD & Phase I clinical trials \\
\hline & Tolerogenic dendritic cells & $\begin{array}{l}\text { Modulate cytokines secretion, expand Foxp3 } 3^{+} \text {Treg, } \\
\text { and suppress allo-CD4+ T cell proliferation }\end{array}$ & aGVHD & Preclinical animal study \\
\hline & Mesenchymal stromal cells & $\begin{array}{l}\text { Regulate immunity by interacting with innate } \\
\text { immune cells and adaptive immune cells }\end{array}$ & aGVHD & Being used in clinic \\
\hline & $\mathrm{MSC}^{-I C O S-E G F P}$ & $\begin{array}{l}\text { Induce CD4+ T cell apoptosis, suppress Th1 and } \\
\text { Th17 polarization, and promote Th2 polarization }\end{array}$ & aGVHD & Preclinical animal study \\
\hline & Coating donor $\mathrm{T}$ cells & $\begin{array}{l}\text { Block the direct contact between donor } \\
\text { T cells and host APCs }\end{array}$ & aGVHD & Preclinical animal study \\
\hline \multirow[t]{5}{*}{ mAbs to cytokines } & $\begin{array}{l}\text { Daclizumab (humanized } \\
\text { IL-2R } \alpha \text { mAb) }\end{array}$ & Inhibit activated alloreactive T cells & $\begin{array}{l}\text { Gastrointestinal and hepatic } \\
\text { aGVHD, } \\
\text { steroid-refractory aGVHD } \\
\text { (SR-aGVHD) }\end{array}$ & Being used in clinic \\
\hline & Basiliximab (IL-2R $\alpha$ mAb) & Inhibit activated alloreactive T cells & aGVHD and cGVHD & Being used in clinic \\
\hline & Inolimomab (IL-2R $\alpha$ mAb) & Inhibit activated alloreactive $T$ cells & SR-aGVHD & Being used in clinic \\
\hline & Infliximab & $\begin{array}{l}\text { Inhibit TNF-alpha signaling and functions } \\
\text { of T cells, NK cells, B cells, and APCs }\end{array}$ & SR-aGVHD & Being used in clinic \\
\hline & Etanercept & $\begin{array}{l}\text { Inhibit TNF-alpha signaling and functions } \\
\text { of T cells, NK cells, B cells and APCs }\end{array}$ & Skin and gut aGVHD & Being used in clinic \\
\hline
\end{tabular}

aGVHD, acute graft-versus-host disease; APC, antigen-presenting cell; cGVHD, chronic graft-versus-host disease; mAb, monoclonal antibody. 


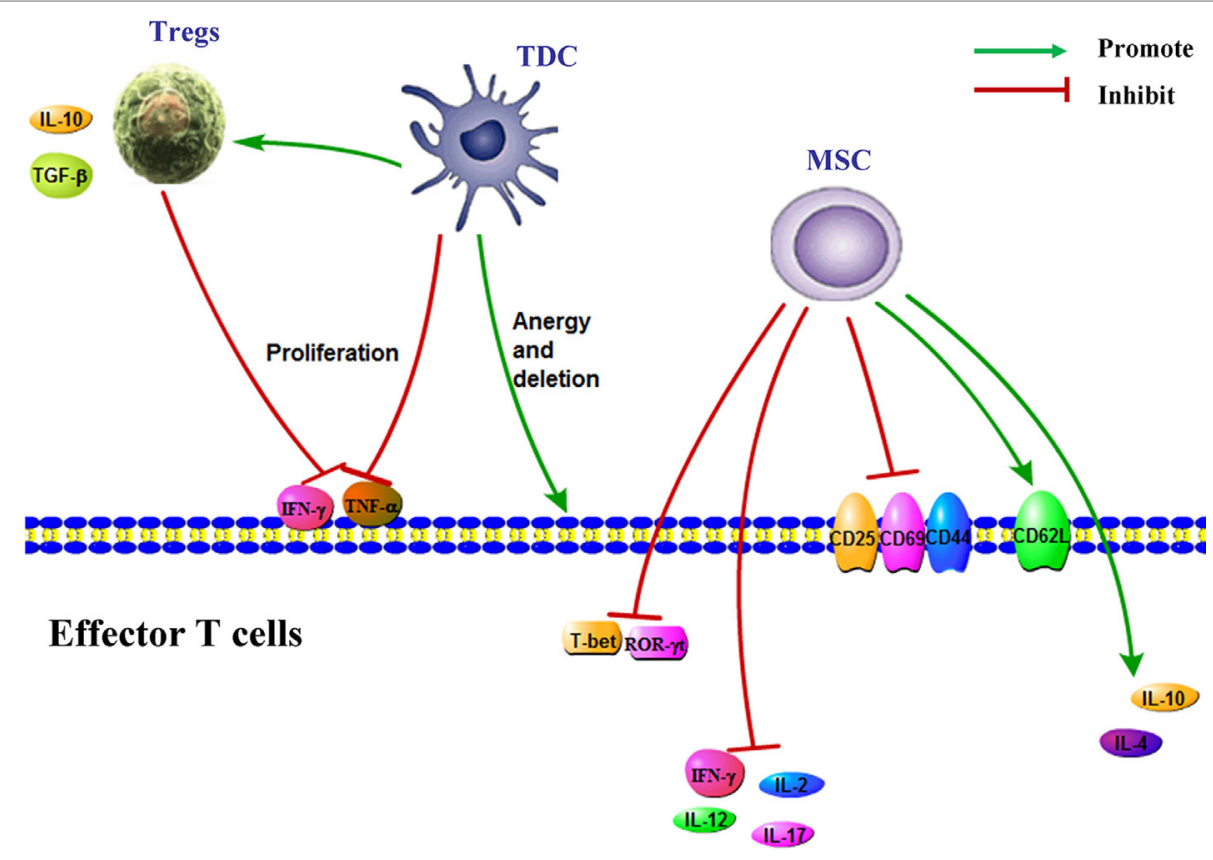

FIGURE 1 | Immune cells for the treatment of Graft-versus-host disease. Regulatory T cells (Tregs) secret IL-10 and TGF- $\beta$ and inhibit effector T cell proliferation and the production of IFN- $\gamma$ and TNF-alpha. TDCs have low expression of MHC and co-stimulatory molecules, express high levels of immunosuppressive cytokines, expand Foxp3 ${ }^{+}$Treg and suppress allo-CD4+ $\mathrm{T}$ cell proliferation, and induce the anergy and deletion of effector T cell. MSC induce the expression of CD62 $\mathrm{L}$ and the production of IL-4 and IL-10 in T cell and inhibit the expressions of ROR- $\gamma \mathrm{t}, \mathrm{CD} 25$, CD69, and CD44 and proinflammatory cytokines production. Abbreviations: MSC, mesenchymal stem cell; TDC, tolerogenic dendritic cells; Treg, regulatory T cell.

allogeneic cell and organ transplantations. It was more efficient that alloantigen-specific Tregs controlled mice GVHD than that of polyclonal Tregs (24).

Clinical trials have been showed that Tregs had potential effects in preventing GVHD in patients undergoing allo-HSCT. Six independent trials showed the feasibility and safety of Tregbased approaches. Either freshly isolated or ex vivo expanded $\mathrm{FOXP}^{+}$Tregs were infused in patients undergoing allo-HSCT for onco-hematological diseases. Treg-treated patients, the cumulative incidence of relapse was significantly lower than in historical controls. The group of M. G. Roncarolo has completed a phase-I clinical trial in which IL-10-anergized T cells containing Tregs were injected in patients undergoing haploidentical-HSCT. Donor-derived IL-10-anergized T cells specific for host alloantigens were generated in vitro through activation of $\mathrm{T}$ cells by host-derived APCs in the presence of exogenous IL-10. M. G. Roncarolo demonstrated that no acute adverse events and only mild GVHD (grades II or III responsive to therapy) were observed after infusion of IL-10- anergized T cells $(25,26)$.

In addition to the role of $\mathrm{CD} 4^{+}$Tregs in suppressing excessive immune responses, $\mathrm{CD} 8^{+}$Tregs have also been reported to contribute in maintaining immune tolerance. Human alloantigenspecific CD $8^{\text {hi }}$ Tregs have been generated in a large scale by Tu's research group from University of Hong Kong. Tu's research group demonstrated that ex vivo-induced $\mathrm{CD} 8^{\text {hi }}$ Tregs controlled GVHD in an allospecific manner by reducing alloreactive $\mathrm{T}$ cell proliferation as well as decreasing inflammatory cytokine and chemokine secretion within target organs through a CTLA-4 dependent mechanism. These $\mathrm{CD} 8^{\text {hi }}$ Tregs induced long-term tolerance effectively without compromising general immunity and graft-versus-tumor activity (27).

Martelli et al. reported that donor-derived Tregs, coinfused with conventional $\mathrm{T}$ cells (Tcons), could protect recipients against GVHD and prevent posttransplant leukemia relapse in phase II study (28). These findings demonstrate the immunosuppressive potential of Tregs in suppressing GVHD without loss of the benefits of graft-versus-leukemia (GVL) activity. It is very encouraging that the results of clinical trials applying Tregs in allo-HCT, which provides a basis for solid organ transplantation in future trials.

\section{Treatment of GVHD With TDCs}

The activation of DCs from donor and recipient plays an important role in the initiation of GVHD. Donor T cells could be activated by host DCs alone. TDCs are essential for both peripheral and central tolerance (29). In thymus, TDCs take part in the autoreactive immature $\mathrm{T}$ cells deletion through presenting self-antigens. In periphery, the interactions between TDCs and $\mathrm{T}$ cells induce tolerance and the subsequent induction of Tregs, $\mathrm{T}$ cell deletion, and T cell anergy (30). TDCs express high levels of immunosuppressive cytokines and express low levels of MHC and co-stimulatory molecules. TDCs could reduce the severity of aGVHD by expanding Foxp $3^{+}$Treg, suppressing allo-CD $4^{+} \mathrm{T}$ cell proliferation and decreasing cytokines secretion. TDCs potently induce and maintain tolerance to a greater extent compared with conventional DCs. Donor or host TDCs promote allograft 
survival in mice. Furthermore, the levels of IL-10 and TGF- $\beta$ in serum were significantly increased and the percentage of Foxp $3^{+}$ cells continually elevated in the mice treated with TDCs (31) (Figure 1).

The use of TDC has shown great potential, and administration of TDC prolongs graft survival. Recipient DCs, donor DCs, or donor antigen-pulsed recipient DCs have been used in preclinical studies. Compared to immune inhibitor alone, autologous TDCs and suboptimal immune inhibitor combination are able to induce antigen specifical graft tolerance and long-term allograft survival. Similar TDCs in different animal models (mice and non-human primates) were derived, and the protective abilities of these TDCs were confirmed in vitro and in vivo. In rats, mice, and nonhuman primates, bone marrow progenitors cultured with low doses of granulocyte macrophage colony-stimulating factor could generate TDCs. Autologous TDCs are more effective than allogeneic TDCs in prolonging allograft survival. The mechanisms involved in the tolerance induced by autologous TDC might be that autologous TDC could specifically induce INF-gamma production by $\mathrm{TCR} \alpha \beta^{+} \mathrm{CD} 3^{+} \mathrm{CD} 4^{-} \mathrm{CD} 8^{-}$cells (double-negative T cells). It indicates the practical advantages of autologous TDCs as a therapeutic tool in clinic. This strategy may also help reduce the immunosuppressive load in grafted patients and, therefore, limit the harmful effects of immune inhibitors (32-34). The studies of TDCs in aGVHD treatment have being in preclinical study phase.

\section{Mesenchymal Stromal Cells for the Treatment of GVHDs}

As a heterogeneous cell population, human multipotent mesenchymal stromal cells (MSCs) are present in many tissues and have immunomodulatory properties. MSCs downregulate immunity by interacting with innate immune cells [including macrophages, natural killer (NK) cells, and DCs], and adaptive immune cells (including B and T cells). MSCs have been clinically applied to treat autoimmune diseases and $\operatorname{GVHD}(35,36)$. Since a 9-year-old boy with SR-aGVHD was first treated with haploidentical thirdparty derived MSCs, a number of clinical trial studies have suggested that MSC infusion might be effective and safe in aGVHD treatment (37). A phase II/III study using MSCs for grades II or III aGVHD was conducted by Muroi et al. 25 patients (grade IV, 3 patients and grade III, 22 patients) were enrolled and treated with MSC infusions. The rate of CR and partial response (PR) was $24 \%$ (6 patients) and $36 \%$ (9 patients), respectively, at 4 weeks after the first MSC infusions. And the adverse drug reaction commonly associated with MSC was not found. This result suggested that MSCs was effective for SR-aGVHD (38). The safety and feasibility of bone marrow-derived MSC was assessed in a phase I multicenter study with 40 patients. Overall response rate (ORR) was $67.5 \%$, with $27.5 \% \mathrm{CR}$. The overall survival rate at 1 and 2 years was 50.0 and $38.6 \%$, respectively, and the median survival time was 1.1 years from the first MSC administration (39). These findings show that MSC can be safely administered on top of conventional immunosuppression for SR-GVHD treatment.

Dotoli et al. reported that 46 patients received treatment with MSC infusion as salvage therapy for SR-aGVHD III/IV. The cumulative dose of MSCs was $6.81 \times 10^{6} / \mathrm{kg}$ in a median of three infusions (range, 1-7). Result showed that 50\% (23/46) presented clinical improvement all of the patients, The CR rate and PR rate was 13 and $61 \%$, respectively. And $26 \%$ patients presented transient PR. $4.3 \%$ patients had acute side effects, such as blurred vision, vomiting, nausea, and cell infusion. These results show that this kind of therapeutic way is safe for SR-aGVHD (40). Placenta-derived decidual stromal cells (DSCs) are more immunosuppressive than MSCs and are used for aGVHD after HSCT as a novel therapy. Baygan et al. assessed the safety and adverse events of DSCs in 44 patients, and 40 controls were given. The result showed that 1-year survival rate was $67 \%$ for DSC treatment in GVHD patients, which was significantly better than control group (41). Jurado et al. reported adipose tissue-derived MSCs may be considered safe and feasible for cGVHD in combination with immunosuppressive therapy, which would likely have an impact on the course of cGVHD (42).

MSC ameliorated the pathological changes of liver and gut, and increased significantly survival in mouse aGVHD model. MSC therapy could directly inhibit the proliferation of donor $\mathrm{CD}^{+} \mathrm{T}$ cell and reduce the production of TNF-alpha (43). The beneficial effect of human MSCs was also associated with the alternation multiple aspects of mouse T cell activation. Moreover, the effects are specific to MSCs, non-MSC control cell lines were incubated with $\mathrm{T}$ cells, which had no any effects on the proliferation and activation of T cell (44). Bone marrow MSCs inhibit $\mathrm{CD}^{+} \mathrm{T}$ cell-mediated activation by decreasing the secretion of indoleamine 2 , PGE2, TGF- $\beta$, and 3-dioxygenase and reducing the expression of natural-killer group 2, member D (NKG2D, activating/co-stimulatory receptor) (45) (Figure 1).

However, the safety of MSC has been focused attention on the possible malignant transformation due to mutations acquired during the large-scale expansion in vitro. A few studies described spontaneous oncogenic transformation in murine MSC (46). In order to investigate the frequency of cytogenetic alterations in a broad "collection" of clinical-grade BM-MSC products, Capelli et al. performed cytogenetic analysis of preparations expanded under Good Manufacturing Practice conditions. Their conclusion was that the presence frequency of spontaneous, non-clone, and non-recurrent mutations was not low, but the clone mutations obtained were not associated with a malignant transformation and transformed phenotype in vitro (47). Nevertheless, for safety reasons, the lack of clone chromosome aberrations or the presence of non-clone chromosome anomalies on $10 \%$ or less of metaphases were set as release criteria before MSC distribution for exploitation in clinical trials (48).

MSC $^{\text {-ICOS-EGFP }}$ is a potent strategy for the prevention and treatment of aGVHD. MSC-ICOS-EGFP could induce more the apoptosis of $\mathrm{CD}^{+} \mathrm{T}$ cell and suppress the polarization of Th17 and Th1, and promote Th2 polarization. In the MSC ${ }^{-I C O S-E G F P ~}$ treatment group, the levels of IL-4, IL-10 in serum were high, and the low levels of IL-2, IFN- $\gamma$, IL-12, IL-17A were found. MSC ${ }^{\text {-ICOS-EGFP }}$ could also induce the expression of STAT6, GATA-3 and inhibit STAT4, T-bet, ROR- $\gamma$ t expression (49). Despite substantial progress, how MSCs module immune responses during an aGVHD episode remains to be elucidated. The future studies of MSCs in aGVHD will lead to stepwise improvements in product selection, timing, dose, frequency, and method of administration. The optimization 
of MSC infusion therapy in aGVHD may supports the best use of MSC in other diseases of immunity and inflammation.

\section{Nanoencapsulation of Allogeneic T Cells Mitigates GVHD}

The activation of recipient APCs and donor T cells play key roles in the initiation progress of aGVHD. Therefore, the blockade of donor $\mathrm{T}$ cell activation by systemic immunosuppression is a common approach to combat aGVHD $(50,51)$. Coating donor T cells with nanoscale biocompatible and biodegradable film without significantly changing the size and surface charge of $\mathrm{T}$ cells is desired to block the direct contact between host APCs and donor $\mathrm{T}$ cells to minimize GVHD in allogeneic transplantation. In our lab, we tested if the temporary immunoisolation achieved by coating donor $\mathrm{T}$ cells with a biodegradable and biocompatible porous film of alginate and chitosan could relieve GVHD without compromising GVL effect. The results showed that nanoencapsulation had no impact on the phenotype of $\mathrm{T}$ cells in vitro in terms of viability, proliferation, size, cytokine secretion, and cytotoxicity effect against tumor cells. Lethally irradiated mice were transplanted with the encapsulated allogeneic $\mathrm{T}$ cells and bone marrow cells, the results exhibited that compared to the transplantation of nonencapsulated allogeneic $\mathrm{T}$ cells and BMCs, the survival was significantly improved and GVHD was reduced together with minimal liver damage and enhanced engraftment of donor BMCs. Moreover, the nanoencapsulation did not alter the GVL effect of encapsulated donor T cells (52). This finding suggest that nanoencapsulation of $\mathrm{T}$ cells with nanoscale, biodegradable, and biocompatible porous materials is a potentially effective and safe strategy to improve allogeneic HSC transplantation for hematological malignancies and other inflammatory and immune diseases (Figure 2).

\section{TARGETING CYTOKINES FOR THE TREATMENT OF GVHD}

Inflammatory cytokines secreted by activated T cells, macrophages, DCs, such as TNF- $\alpha$ and IL-2, and so on, are key inflammatory mediators of GVHD and may be important therapy targets. Various mAbs to cytokines secreted by effector cells in GVHD have been researched for aGVHD treatment. These mAbs include anti-TNF- $\alpha$ antibodies, IL-2 receptor antagonists, and so on (Table 1). Overall, the response rates are about greater than $60 \%$, although the long-term survival still remains suboptimal (53).

\section{Interleukin-2 Receptor Antagonists and Ultra Low-Dose IL-2}

The mAbs of IL-2 receptor targeting activated T cells have been investigated in SR-aGVHD treatment. Daclizumab is a humanized $\mathrm{mAb}$ against IL-2 receptor alpha subunit (IL-2Ra) and has been demonstrated to be effective and safe for adults refractory GVHD. Hamidieh et al. reported that daclizumab was given intravenously, and then was given again on a 10- to 14-day interval for maximum five times if necessary. The results showed that the long-term evaluation of daclizumab might be relatively safe and

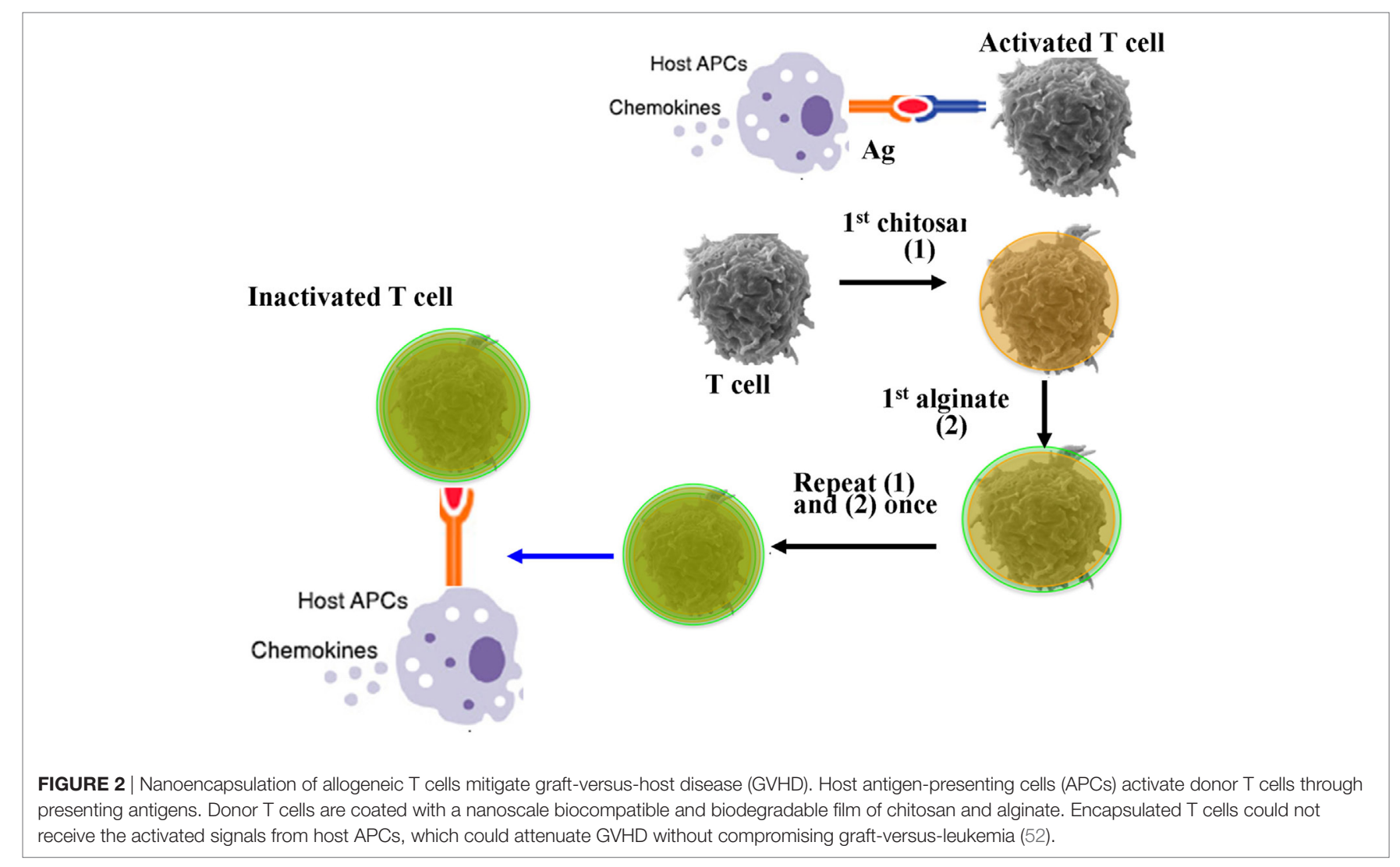


effective treatment in most of the severe SR pediatric patients with gastrointestinal aGVHD, although infection occurred frequently. 10 patients responded completely to daclizumab, only one patient responded partially to daclizumab, while there were remaining two patients failing to respond (54). 13 pediatric patients with refractory aGVHD were treated with daclizumab. After 30 days of daclizumab treatment, the CR rate and PR rate was 46 and $46 \%$, respectively, in all patients, the $C R$ rate and $P R$ rate were both higher than that of control group. Moreover, the cutaneous aGVHD patients achieved CR. 50 and 30\% had CR and PR, respectively, in gastrointestinal patients, whereas 11 and $55 \%$ of hepatic aGVHD patients reached CR and PR, respectively (55).

Combination treatment with infliximab and daclizumab is an effective therapy for SR-aGVHD patients and might be associated with decreased infection-related mortality compared to the monotherapy of infliximab or daclizumab (56). Seventeen GVHD received a combination anti-cytokine therapy of daclizumab and infliximab. This result suggested that the combination of anti-cytokine therapy of infliximab and daclizumab has significant activity in aGVHD (57). Basiliximab, another monoclonal antibody against IL-2Ra, prevents graft failure in renal transplantation and is also capable to effectively treat SR-GVHD. The side effects of daclizumab and basiliximab were tolerable and moderate. The prophylactic effects of daclizumab or basiliximab against GVHD in 82 peripheral blood stem cell transplantation patients were evaluated. The incidence rate of grades II-IV and III-IV aGVHD were 35.4 and $15.9 \%$, respectively. $38.7 \%$ of evaluable patients suffered from cGVHD. Daclizumab or basiliximab could contribute to favorable outcome by preventing GVHD efficiently. Compared to daclizumab, basiliximab has superior activity against cGVHD, although has a similar effect on $\operatorname{aGVHD}(58,59)$. Inolimomab (anti-IL-2R $\alpha$ ) is a mAb targeting IL-2 receptor subunit CD25 that predominantly inhibits activated alloreactive T cells. Several reports have showed encouraging results in SR-aGVHD treatment with inolimomab (60). But the combination of etanercept and inolimomab failed to improve the dismal prognosis of severe SR-aGVHD (61). Ultra low-dose (ULD) IL-2 could expand Tregs without diminishing antileukemic activity and antiviral activity in GVHD treatment. Tregs expressing high level of IL-2 receptor may selectively expand in response to low-dose IL-2 insufficient to stimulate effector T cell populations, thereby preventing GVHD (62).

\section{Anti-TNF Alpha mAbs}

Infliximab is an anti-TNF alpha $\mathrm{mAb}$ that is effective for treatment of patients with SR-aGVHD $(15,63)$. However, some studies show controversial results. Couriel's research group reported that 63 refractory aGVHD patients were included and randomized to receive either steroid therapy alone or steroid plus infliximab. Results showed that there were not significantly different between the two groups in GVHD-related mortality, non-relapse mortality, and overall survival (63). The possible explanation is that CD4 ${ }^{+}$Tregs express TNF receptor type 2 (TNFR2) and TNF-alpha could increase Treg activity through TNFR2. The sole defect of TNF production by donor T cells was sufficient to completely abolish the Treg suppressive effect in GVHD. Infliximab might reduce the inhibitory activity of Treg. The control of GVHD by
Tregs was fully abolished by blocking TNFR2 or TNFR2-deficient Tregs (64).

Anti-TNF-alpha treatment enables to reduce corticosteroid dose without aggravating GVHD. Reduction of methylprednisolone and administration of infliximab could get rapid improvement of depression induced by steroid without aggravating GVHD (65).

Etanercept is a fusion protein of recombinant human soluble TNF-alpha receptor and has a modest effect on SR-aGVHD with tolerable side effects (66). 13 SR-aGVHD patients received etanercept therapy, six patients responded to etanercept, and the best response was seen in the patients with gastrointestinal aGVHD (67). The patients with grade I aGVHD receiving etanercept and topical corticosteroids showed a more decrease in the progression of grade than that of control group with corticosteroids alone (68). Etanercept had a down-grading effect on aGVHD, although no patient experienced a complete remission. In addition, gut and skin GVHD were also well controlled by etanercept, whereas hepatic GVHD was not the case (69).

\section{TARGETING CD MOLECULES FOR THE TREATMENT OF GVHD}

Effector cells involving in GVHD express many CD molecules, these $\mathrm{CD}$ molecules promote the differentiation, activation, maturation, and survival of effector cells. mAbs to CD molecules on cell surface have being investigated for GVHD treatment. These mAbs include anti-CD83, anti-CD132, anti-CD20, and anti-CD28 mAbs, and so on (Table 2), while anti-CD20 mAb has been extensively studied in CGVHD (53).

\section{Soluble CD83 Molecules}

CD83 belongs to immunoglobulin (Ig) superfamily and is a highly glycosylated type I transmembrane glycoprotein. As a marker of mature DCs, CD83 is expressed on DCs and activated lymphocytes and is essential for longevity of $\mathrm{CD} 4^{+} \mathrm{T}$ cells and thymus maturation. In addition, CD83 is also involved in the maturation, homeostasis, and function of peripheral $\mathrm{B}$ cell (70). Soluble CD83 (sCD83) may be derived from proteolytic cleavage of membrane-bound CD83. It has been demonstrated that sCD83 has therapeutic effects against GVHD by blocking CD83-ligand interaction in animal models. sCD83 is capable of inducing donor-specific allograft tolerance and attenuating DC maturation, and also inhibits the proliferation of DC-dependent allopeptide-specific $\mathrm{T}$ cell to prevent the rejections of cardiac allograft. Furthermore, sCD 83 could also attenuate innate and adaptive immune responses, which results in preventing chronic rejection in a rat model with renal transplant $(71,72)$.

\section{Anti-CD83 Antibodies}

It has been found that polyclonal or mAbs targeting CD83 can reduce GVHD symptoms through depleting activated $\mathrm{CD}^{+}$effector $\mathrm{T}$ cells and $\mathrm{CD}^{+} 3^{+}$DCs. In a human $\mathrm{T}$ celldependent peripheral blood mononuclear cell transplanted SCID (hu-SCID) model, CD83 antibody suppressed the alloproliferation of T lymphocytes but did not prevent engraftment of human $\mathrm{T}$ cells, including cytotoxic T lymphocytes (CTL) responsive to viruses and malignant cells. Polyclonal CD83 antibody for GVHD 
TABLE 2 | Monoclonal antibodies (mAbs) to CDs and signaling molecules for the treatment of graft-versus-host disease (GVHD).

\begin{tabular}{|c|c|c|c|c|}
\hline $\begin{array}{l}\text { Different } \\
\text { classes }\end{array}$ & Cells or agents & Mechanisms & Types of GVHD & Clinical translation \\
\hline \multirow[t]{6}{*}{ mAbs to CDs } & sCD83 antibody & $\begin{array}{l}\text { Inhibits DC-dependent cell proliferation } \\
\text { and attenuate DC maturation }\end{array}$ & $\begin{array}{l}\text { Prevent aGVHD in cardiac } \\
\text { allograft }\end{array}$ & Preclinical animal study \\
\hline & Rituximab (CD20 mAb) & $\begin{array}{l}\text { Modulates cytokines secretion, expands } \\
\text { Foxp3 + Treg, and suppresses allo-CD4+ T cell }\end{array}$ & $\begin{array}{l}\text { Prevent cGVHD and preserve } \\
\text { graft-versus-leukemia effect }\end{array}$ & Being used in clinic \\
\hline & Anti-CD132 mAb & Inhibits granzyme B production in CD8+ T cells & $\begin{array}{l}\text { Reverse liver and lung } \\
\text { fibrosis in cGVHD }\end{array}$ & Phase II clinical trials \\
\hline & Anti-CD45RC mAb & $\begin{array}{l}\text { Induced rapid death of CD45RC high } \\
\mathrm{T} \text { cells through intrinsic cell signaling }\end{array}$ & $\begin{array}{l}\text { Inhibited aGVHD in immune- } \\
\text { humanized NSG mice }\end{array}$ & Preclinical animal study \\
\hline & Anti-CD28 mAb & $\begin{array}{l}\text { Suppress effector } T \text { cells, enhance regulatory } \\
\mathrm{T} \text { cells function and immune tolerance }\end{array}$ & Prevent aGVHD in mice & Preclinical animal study \\
\hline & Anti-CD28 Fab antibody & Inhibits T cell expansion & $\begin{array}{l}\text { Prevented aGVHD and } \\
\text { cGVHD in mice }\end{array}$ & Preclinical animal study \\
\hline \multirow[t]{5}{*}{$\begin{array}{l}\text { Signaling } \\
\text { molecules }\end{array}$} & DNMAML1 & $\begin{array}{l}\text { Blocks notch receptors and decreased } \\
\text { Ras/MAPK and NF-кB activity }\end{array}$ & $\begin{array}{l}\text { Decreased mortality and } \\
\text { severity of aGVHD }\end{array}$ & Preclinical animal study \\
\hline & R788 (inhibitor of Syk) & $\begin{array}{l}\text { Downregulate the expressions of CXCR4, } \\
\text { MCP-1, MIP-1alpha, IFN-gamma, IL-13, IL-17A }\end{array}$ & $\begin{array}{l}\text { Attenuated the severity } \\
\text { and fibrosis of cGVHD }\end{array}$ & Preclinical animal study \\
\hline & $\begin{array}{l}\text { PIAS3 [signal transducer and activator } \\
\text { of transcription } 3 \text { inhibitor (STAT3)] }\end{array}$ & $\begin{array}{l}\text { Blocks the IL-2-induced proliferation } \\
\text { and provides selected immunosuppression }\end{array}$ & $\begin{array}{l}\text { Attenuates the clinical } \\
\text { and histopathological } \\
\text { severities of aGHVD }\end{array}$ & Preclinical animal study \\
\hline & $\begin{array}{l}\text { KD025 (Rho-associated coiled-coil } \\
\text { containing protein kinase2 inhibitor) }\end{array}$ & $\begin{array}{l}\text { Inhibits the secretion of IL-21, IL-17, } \\
\text { and IFN- } \gamma \text {, decreases phosphorylated STAT3 }\end{array}$ & $\begin{array}{l}\text { Suppresses murine } \\
\text { and human cGVHD }\end{array}$ & Preclinical animal study \\
\hline & Ruxolitinib (Janus kinases 1/2 inhibitor) & $\begin{array}{l}\text { Impairs the differentiation of CD4+ T cells } \\
\text { and increases FoxP3+ regulatory } T \text { cells }\end{array}$ & aGVHD and cGVHD & $\begin{array}{l}\text { Multiple centers clinical } \\
\text { trials }\end{array}$ \\
\hline
\end{tabular}

aGVHD, acute graft-versus-host disease; APC, antigen-presenting cell; cGVHD, chronic graft-versus-host disease; DNMAML1, Dominant negative form of Mastermind-like 1; mAb, monoclonal antibody; UCBT, umbilical cord blood transplantation.

has been suggested to have the outcome of depletion of $\mathrm{CD} 83^{+}$ DCs and mediates to suppress T cell proliferation. Anti-CD83 antibody treatment may leave tolerogenic and nonactivated CD83-tolerogenic DCs, which may induce Tregs with potential allo-suppressive benefits. Since activated $\mathrm{CD} 4^{+} \mathrm{T}$ cells also express CD83, anti-CD83 antibodies may also deplete the activated CD4 ${ }^{+}$ effector T cells $(73,74)$. Therefore, administration of anti-CD83 antibodies may attenuate GVHD. Investigating the underlying mechanisms is likely to provide improved control of GVHD.

\section{Anti-CD20 Monoclonal Antibody}

$B$ cells involve in the pathogenesis of cGVHD. Rituximab, which is a monoclonal antibody of anti- CD20, has been investigated in cGVHD treatment and demonstrated to have some benefit. Cutler et al. reported that the response rate was $70 \%$ in 21 steroidrefractory cGVHD patients treated by rituximab (75). Similarly, the response rate to rituximab therapy was $66 \%$ in seven studies involving 111 patients by meta-analysis (76). Before the signs of cGVHD, administration of anti-CD20 mAb can prevent the induction of autoimmune-like cGVHD and preserve GVL effect; however, there is little effect if rituximab is administered after cGVHD onset (77).

\section{Anti-CD132 Monoclonal Antibody}

CD132 is a subunit of the common gamma chain of the interleukin receptors for IL-2, IL-7, IL-9, IL-4, IL-21, and IL-15. The levels of these cytokines were shown to be high in aGVHD and cGVHD patients. Anti-CD132 monoclonal antibody could potently reduce aGVHD with respect to survival, GVHD histopathology, and the production of cytokines, such as TNF, IFN- $\gamma$, and IL-6. Anti-CD132 mAb afforded the protection from GVHD partly through inhibiting the production of granzyme $\mathrm{B}$ in $\mathrm{CD}^{+} \mathrm{T}$ cells. Also, $\mathrm{T}$ cells treated with anti-CD132 mAb displayed naive phenotype and showed decreased phosphorylation of JAK3. Additionally, anti-CD132 mAb reversed liver and lung fibrosis, and pulmonary dysfunction in the treatment of established cGVHD comparing with control group (78).

\section{Anti-CD45RC Monoclonal Antibody}

CD45RC, a different isoform of CD45, plays an important role in thymocyte maturation and $\mathrm{T}$ cell activation and function. CD45RC is expressed at high levels on B cells, NK, and CD8 ${ }^{+}$ $\mathrm{T}$ cells. $\mathrm{CD}^{+}$and $\mathrm{CD}^{+}{ }^{+}$Foxp3 $3^{+}$Tregs do not express CD45RC and have strong immunoregulatory properties. Anti-CD45RC is a potent therapeutic candidate to induce transplantation tolerance in human. Anti-human CD45RC treatment inhibited GVHD in immune-humanized NSG mice. Administration of anti-CD45RC antibody could induce transplant tolerance associated with inhibition of allogeneic humoral responses in a rat cardiac allotransplantation model. Compared to control group, anti-CD45RC mAb induced rapid death of CD45RC $\mathrm{Cigh}^{\mathrm{T}} \mathrm{T}$ cells through intrinsic cell signaling, and preserved $\mathrm{CD} 4^{+}$and $\mathrm{CD} 8^{+}$ CD45RC ${ }^{\text {low/- }}$ Tregs, which are able to adoptively transfer donorspecific tolerance to grafted recipients (79).

\section{Agonistic Anti-CD28 Monoclonal Antibody}

Anti-CD28 monoclonal antibody targeting CD28 costimulatory molecule may be used as novel therapeutic agents to abrogate 
pathogenic $\mathrm{T}$ cell responses by selective depletion of activated T cells. Anti-CD28 antibodies differentiate from CTLA4Ig and cannot block CTLA-4 and PDL-1 coinhibitory signals. Anti-CD28 antibodies have the efficacies in suppressing effector T cells while enhancing Tregs function and immune tolerance. Administration of anti-CD28 mAb could inhibit donor T cell expansion and T cell costimulation and prevent GVHD in mice. Anasetti team found that anti-CD28 treatment prevented GVHD by selectively depleting alloantigen-activated donor T cells. Depletion of activated $\mathrm{T}$ cells mediated through CD28 did not depend on the expression of death receptors Fas, TNFRI, and TNFRII (80). FR104 is a novel humanized pegylated anti-CD28 Fab antibody fragment presenting a long elimination half-life in monkeys. In vitro, compared to control group, FR104 failed to induce human T cell proliferation and cytokines secretion, even in the presence of anti-CD3 antibodies. Administration of FR104 inhibited T cell expansion and prevented GVHD in humanized NOD/SCID mice in a CTLA4-dependent manner (81).

\section{TARGETING SIGNALING MOLECULES FOR THE TREATMENT OF GVHD}

Inflammatory cytokines, such as IL-2, TNF- $\alpha$, and IL-17, and so on, mediate some signaling pathways through binding to receptor. These signaling pathways, such as Notch signaling pathway, Janus kinase (JAK)/STAT signaling pathway, participate in gene expression, cells interaction, cell proliferation, and activation, and so on in the pathological process of GVHD. Various inhibitors targeting key molecules in signaling pathways in GVHD have been investigated for GVHD treatment (Table 2).

\section{Notch Inhibitor for the Treatment of GVHD}

Notch signaling is a cell-cell communication pathway, which plays an important role in the development and immunity of T cell. Notch ligands bind to four Notch receptors (Notch1-4), which leads to the activation of proteolytic receptor. Dominant negative form of Mastermind-like 1 (DNMAML1) blocks the transcriptional activation downstream of all Notch receptors. DNMAML1 markedly decreased mortality of aGVHD in mice. DNMAML1 in donor $\mathrm{T}$ cells led to decreasing aGVHD severity markedly, without causing global immune suppression. Alloreactive T cells expressing DNMAMLI displayed increased expansion of Tregs and decreased production of inflammatory cytokines, leading to attenuating target organ damage (82) In addition, alloreactive $\mathrm{T}$ cells expressing DNMAMLI could also decrease the activation of Ras/MAPK and NF- $\mathrm{BB}$ signaling pathways (83) (Figure 3).

\section{Inhibition of c-Rel}

NF- $\kappa \mathrm{B}$ signaling plays important roles in immunity and oncogenesis and might be therapeutic targeting. $\mathrm{c}-\mathrm{Rel}$ is one of NF- $\mathrm{KB}$ family members and a subunit of NF- $\kappa$ B. A novel strategy was developed that to ameliorate GVHD while preserving GVT activity by suppression of c-Rel (84). IT-901, which is a bioactive derivative of naphthalene thiobarbiturate, could potently suppress GVHD and preserve GVL effect though inhibiting c-Rel in allogeneic transplantation. The major mechanisms of IT-901 were to reduce alloactivation and impaire negative feedback on

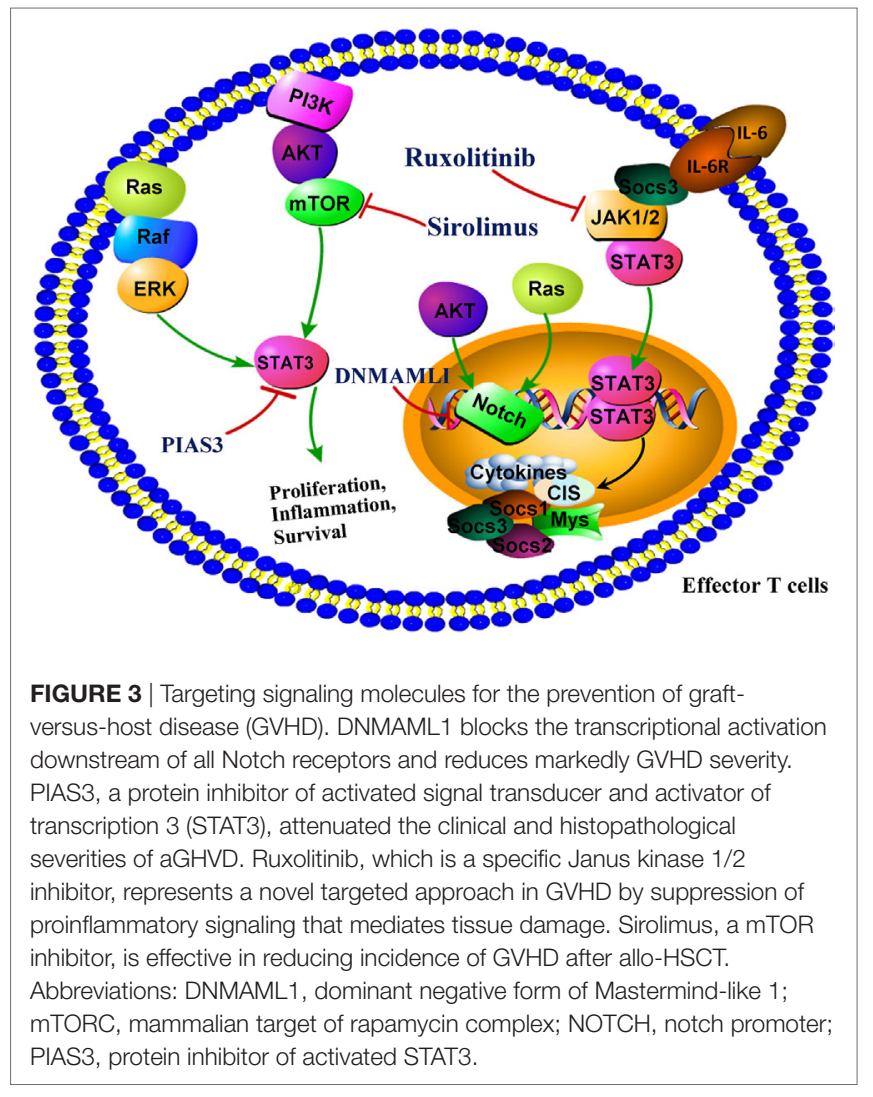

IL-2 production, resulting in the expansion of Tregs. Further preclinical assessment revealed the antitumor properties of IT-901 in the treatment of human B-cell lymphoma. This finding suggests that IT-901 is a novel therapeutic agent to ameliorate GVHD and treat lymphoid tumors (85).

\section{Syk Inhibitor}

Syk, which is a protein tyrosine kinase, plays a key role in transmitting signals from receptors on cell surface. Syk phosphorylation

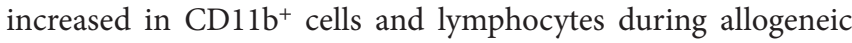
transplantation. R788 is a potent inhibitor of Syk and attenuates the severity and fibrosis of cGVHD. The elevated expression of CXCR4 on T cells, B cells, and CD11 $\mathrm{b}^{+}$cells was significantly downregulated by R788. In addition, compared to control group, R788 inhibited the proliferation of $\mathrm{CD}_{11} \mathrm{~b}^{+}$cells and reduced mRNA expression levels of MCP-1, MIP-1alpha, IFN-gamma, IL-13, IL-17A, and TGF-betal in skin comparing with control group (86).

\section{Inhibitor of Signal Transducer and Activator of Transcription 3 (STAT3)}

Signal transducer and activator of transcription 3 is a pivotal transcription factor for Th17 differentiation. The roles of STAT3 in cGVHD were demonstrated in mice model. Mice transplanted with inducible STAT3-deficient T cells had the same pulmonary function as healthy negative controls (87). PIAS3, a protein inhibitor of STAT3, inhibits STAT3 activation and significantly ameliorates the histopathology and clinical severities of aGHVD 
involving liver, lung, intestine, and skin comparing with control group. Inhibition of aGVHD by PIAS3 was largely associated to upregulating Th2 and Treg and downregulating Th17 and Th1 (88) (Figure 3).

KD025 is a selective inhibitor of Rho-associated coiled-coil containing protein kinase 2 and effectively attenuates cGVHD in multiple animal models. Mice treated with KD025 resulted in normalization of pulmonary function, which resulted from a marked reduction of collagen deposition and antibody in lungs. Compared to control group, the frequency of $\mathrm{T}$ follicular helper cells decreased and $\mathrm{T}$ follicular regulatory cells increased in the spleens of mice treated with KD025, at the same time, STAT3 expression decreased. KD025 also inhibits the production of IL-17, IFN- $\gamma$, and IL-21, reduces protein expression of interferon regulatory factor 4 accompanied by decreasing phosphorylated STAT3 in peripheral blood mononuclear cells from the patients with active cGVHD (87).

\section{JAK 1/2 Inhibitor Improve Survival of Mice With aGVHD}

The important roles of host inflammatory response governed by JAK $1 / 2$ have been also highlighted through some novel insights into the pathology of aGVHD. Activated JAK $1 / 2$ are required for $\mathrm{T}$ effector cell responses. Ruxolitinib is a specific JAK $1 / 2$ inhibitor. The potent anti-inflammatory properties of ruxolitinib have been demonstrated by preclinical study. Ruxolitinib might be a novel potential approach for GVHD by suppression of tissue damage mediated by proinflammatory signaling. Ruxolitinib could increase $\mathrm{FoxP}^{+}$Tregs and impair the differentiation of $\mathrm{CD}^{+} \mathrm{T}$ cells into the cells producing IL17A and IFN-gamma $(89,90)$ (Figure 3).

Ruxolitinib was recently employed to treat SR-GVHD and a promising ORRs was found. In a retrospective survey, 95 SR-GVHD patients from 19 stem cell transplant centers in the United States and Europe received ruxolitinib as salvage therapy. Results showed that the ORR in SR-aGVHD was $81.5 \%$, and the ORR in SR-cGVHD was $85.4 \%$. The 6-month survival was 79 and 97.4\% for SR-aGVHD and SR-cGVHD, respectively. The ORR and survival rate were both higher than control group. However, the adverse effects were observed in both SR-aGVHD and

\section{REFERENCES}

1. Martin PJ, Rizzo JD, Wingard JR, Ballen K, Curtin PT, Cutler C, et al. Firstand second-line systemic treatment of acute graft-versus-host disease: recommendations of the American Society of Blood and Marrow Transplantation. Biol Blood Marrow Transplant (2012) 18(8):1150-63. doi:10.1016/j.bbmt. 2012.04.005

2. Zhang L, Chu J, Yu J, Wei W. Cellular and molecular mechanisms in graft-versus-host disease. J Leukoc Biol (2016) 99(2):279-87. doi:10.1189/ jlb.4RU0615-254RR

3. Antin JH. T-cell depletion in GVHD: less is more? Blood (2011) 117(23): 6061-2. doi:10.1182/blood-2011-04-348409

4. Blazar BR, Murphy WJ, Abedi M. Advances in graft-versus-host disease biology and therapy. Nat Rev Immunol (2012) 12(6):443-58. doi:10.1038/nri3212

5. Park H, Choi B, Nguyen J, Fan J, Shafi S, Klokkevold P, et al. Anionic carbohydrate-containing chitosan scaffolds for bone regeneration. Carbohydr Polym (2013) 97(2):587-96. doi:10.1016/j.carbpol.2013.05.023

6. Duramad O, Laysang A, Li J, Ishii Y, Namikawa R. Pharmacologic expansion of donor-derived, naturally occurring $\mathrm{CD} 4(+)$ Foxp3(+) regulatory $\mathrm{T}$ cells
SR-cGVHD patients during ruxolitinib treatment, such as the reactivation of cytomegalovirus and cytopenia (91). Khandelwal et al. reported that ruxolitinib was less efficacy in children HSCT patients with a high rate of reversible adverse effects in children with SR-aGVHD (92).

\section{CONCLUSION}

The physiopathology of GVHD is complicated involving a variety of immune cells and molecules. The treatment and management of GVHD may be proposed, trialed, and ultimately validated. Although there is good evidence supporting treatment of both aGVHD and cGVHD with steroids, clearly there remains an unmet clinical need to develop novel safe therapeutic approaches. Some potential therapy strategies are being found, in particular, the roles of Tregs, TDCs, coating T cell, and MSC in GVHD treatment. IL-2Ra, anti-TNF alpha monoclonal antibody, targeting $\mathrm{CD}$ molecules and signaling molecules have been demonstrated to be effective for GVHD. The effects of Tregs against GVHD are very encouraging, but Tregs might also diminish the GVL effects mediated by NK or T cell. Despite substantial progress, how MSCs module immune responses when administered peripherally during an aGVHD episode remains to be elucidated. However, these therapy strategies remain to be validated in clinic. In addition, individualized therapy should be considered based on the characterization of GVHD pathophysiological mechanisms involved, stages, and subtypes. It is anticipated that the novel therapeutic targets and promising strategies may improve the outcomes of GVHD in the future.

\section{AUTHOR CONTRIBUTIONS}

LZ wrote the paper. JY collected data, and WW revised and wrote the paper.

\section{FUNDING}

This work was supported by the National Natural Science Foundation of China (No. 81673444, 81330081 and 81473223), Anhui province Postdoctoral Science Foundation (No. 2016B134).

reduces acute graft-versus-host disease lethality without abrogating the graft-versus-leukemia effect in murine models. Biol Blood Marrow Transplant (2011) 17(8):1154-68. doi:10.1016/j.bbmt.2010.11.022

7. Nishimori H, Maeda Y, Teshima T, Sugiyama H, Kobayashi K, Yamasuji Y, et al. Synthetic retinoid Am80 ameliorates chronic graft-versus-host disease by down-regulating Th1 and Th17. Blood (2012) 119(1):285-95. doi:10.1182/ blood-2011-01-332478

8. Shin HJ, Baker J, Leveson-Gower DB, Smith AT, Sega EI, Negrin RS. Rapamycin and IL-2 reduce lethal acute graft-versus-host disease associated with increased expansion of donor type CD4+CD25+Foxp3+ regulatory T cells. Blood (2011) 118(8):2342-50. doi:10.1182/blood-2010-10-313684

9. Mielcarek M, Furlong T, O'Donnell PV, Storer BE, McCune JS, Storb R, et al. Post-transplantation cyclophosphamide for prevention of graft-versus-host disease after HLA-matched mobilized blood cell transplantation. Blood (2016) 127(11):1502-8. doi:10.1182/blood-2015-10-672071

10. Scarisbrick JJ, Dignan FL, Tulpule S, Gupta ED, Kolade S, Shaw B, et al. A multicentre UK study of GVHD following DLI: rates of GVHD are high but mortality from GVHD is infrequent. Bone Marrow Transplant (2015) 50(1):62-7. doi:10.1038/bmt.2014.227 
11. Miyamoto T, Takashima S, Kato K, Takase K, Yoshimoto G, Yoshida S, et al. Comparison of cyclosporine and tacrolimus combined with mycophenolate mofetil in prophylaxis for graft-versus-host disease after reduced-intensity umbilical cord blood transplantation. Int J Hematol (2017) 105(1):92-9. doi:10.1007/s12185-016-2093-0

12. Saini N, Nath R, Cerny J. Calcineurin inhibitor-free GVHD prophylaxis with sirolimus and mycophenolate mofetil combination. Ann Hematol (2017) 96(9):1563-8. doi:10.1007/s00277-017-3062-2

13. Khimani F, Kim J, Chen L, Dean E, Rizk V, Betts B, et al. Predictors of overall survival among patients treated with sirolimus/tacrolimus vs methotrexate/tacrolimus for GvHD prevention. Bone Marrow Transplant (2017) 52(7):1003-9. doi:10.1038/bmt.2017.63

14. Zhang J, Chen F, Ueki T, Date H. Imatinib for sclerodermatous graft-versushost disease in lung transplantation. Interact Cardiovasc Thorac Surg (2015) 21(2):260-2. doi:10.1093/icvts/ivv122

15. Yang J, Cheuk DK, Ha SY, Chiang AK, Lee TL, Ho MH, et al. Infliximab for steroid refractory or dependent gastrointestinal acute graft-versus-host disease in children after allogeneic hematopoietic stem cell transplantation. Pediatr Transplant (2012) 16(7):771-8. doi:10.1111/j.1399-3046.2012. 01756.x

16. Verneris MR. Natural killer cells and regulatory T cells: how to manipulate a graft for optimal GVL. Hematology Am Soc Hematol Educ Program (2013) 2013:335-41. doi:10.1182/asheducation-2013.1.335

17. Safinia N, Leech J, Hernandez-Fuentes M, Lechler R, Lombardi G. Promoting transplantation tolerance; adoptive regulatory $\mathrm{T}$ cell therapy. Clin Exp Immunol (2013) 172(2):158-68. doi:10.1111/cei.12052

18. Trzonkowski P, Dukat-Mazurek A, Bieniaszewska M, Marek-Trzonkowska N, Dobyszuk A, Juścińska J, et al. Treatment of graft-versus-host disease with naturally occurring $\mathrm{T}$ regulatory cells. BioDrugs (2013) 27(6):605-14. doi:10.1007/s40259-013-0050-5

19. Hannon M, Lechanteur C, Lucas S, Somja J, Seidel L, Belle L, et al. Infusion of clinical-grade enriched regulatory $\mathrm{T}$ cells delays experimental xenogeneic graft-versus-host disease. Transfusion (2014) 54(2):353-63. doi:10.1111/ trf. 12279

20. Coghill JM, Fowler KA, West ML, Fulton LM, van Deventer H, McKinnon KP, et al. CC chemokine receptor 8 potentiates donor Treg survival and is critical for the prevention of murine graft-versus-host disease. Blood (2013) 122(5):825-36. doi:10.1182/blood-2012-06-435735

21. Locafaro G, Andolfi G, Russo F, Cesana L, Spinelli A, Camisa B, et al. IL-10-engineered human CD4+ Tr1 cells eliminate myeloid leukemia in a HLA class I-dependent mechanism. Mol Ther (2017) 25(10):2254-69. doi:10.1016/j.ymthe.2017.06.029

22. Yolcu ES, Kaminitz A, Mizrahi K, Ash S, Yaniv I, Stein J, et al. Immunomodulation with donor regulatory $\mathrm{T}$ cells armed with Fas-ligand alleviates graft-versus-host disease. Exp Hematol (2013) 41(10):903-11. doi:10.1016/j.exphem.2013.04.016

23. van der Touw W, Cravedi P, Kwan WH, Paz-Artal E, Merad M, Heeger PS. Cutting edge: receptors for $\mathrm{C} 3 \mathrm{a}$ and $\mathrm{C} 5 \mathrm{a}$ modulate stability of alloantigen-reactive induced regulatory T cells. J Immunol (2013) 190(12):5921-5. doi:10.4049/ jimmunol.1300847

24. Cherai M, Hamel Y, Baillou C, Touil S, Guillot-Delost M, Charlotte F, et al. Generation of human alloantigen-specific regulatory T-cells under good manufacturing practice-compliant conditions for cell therapy. Cell Transplant (2015) 24(12):2527-40. doi:10.3727/096368914X683566

25. Trenado A, Sudres M, Tang Q, Maury S, Charlotte F, Grégoire S, et al. Ex vivo-expanded CD4+CD25+ immunoregulatory $\mathrm{T}$ cells prevent graftversus-host-disease by inhibiting activation/differentiation of pathogenic T cells. J Immunol (2006) 176(2):1266-73. doi:10.4049/jimmunol.176.2.1266

26. Gregori S, Passerini L, Roncarolo MG. Clinical outlook for type-1 and FOXP3(+) T regulatory cell-based therapy. Front Immunol (2015) 6:593. doi:10.3389/fimmu.2015.00593

27. Zheng J, Liu Y, Liu Y, Liu M, Xiang Z, Lam KT, et al. Human CD8+ regulatory $\mathrm{T}$ cells inhibit GVHD and preserve general immunity in humanized mice. Sci Transl Med (2013) 5(168):168ra9. doi:10.1126/scitranslmed. 3004943

28. Martelli MF, Di Ianni M, Ruggeri L, Falzetti F, Carotti A, Terenzi A, et al. HLA-haploidentical transplantation with regulatory and conventional T-cell adoptive immunotherapy prevents acute leukemia relapse. Blood (2014) 124(4):638-44. doi:10.1182/blood-2014-03-564401
29. Hilkens CM, Isaacs JD, Thomson AW. Development of dendritic cell-based immunotherapy for autoimmunity. Int Rev Immunol (2010) 29(2):156-83. doi:10.3109/08830180903281193

30. Cools N, Petrizzo A, Smits E, Buonaguro FM, Tornesello ML, Berneman Z, et al. Dendritic cells in the pathogenesis and treatment of human diseases: a Janus Bifrons? Immunotherapy (2011) 3(10):1203-22. doi:10.2217/imt.11.110

31. Yang J, Li R, Ren Y, Yang Y, Xie R, Fan H. Third-party tolerogenic dendritic cells reduce allo-reactivity in vitro and ameliorate the severity of acute graftversus-host disease in allo-bone marrow transplantation. Scand J Immunol (2013) 78(6):486-96. doi:10.1111/sji.12113

32. Moreau A, Varey E, Bériou G, Hill M, Bouchet-Delbos L, Segovia M, et al. Tolerogenic dendritic cells and negative vaccination in transplantation: from rodents to clinical trials. Front Immunol (2012) 3:218. doi:10.3389/ fimmu.2012.00218

33. Hill M, Cuturi MC. Negative vaccination by tolerogenic dendritic cells in organ transplantation. Curr Opin Organ Transplant (2010) 15(6):738-43. doi:10.1097/MOT.0b013e32833f7114

34. Hill M, Thebault P, Segovia M, Louvet C, Bériou G, Tilly G, et al. Cell therapy with autologous tolerogenic dendritic cells induces allograft tolerance through interferon-gamma and epstein-barr virus-induced gene 3. Am J Transplant (2011) 11(10):2036-45. doi:10.1111/j.1600-6143.2011.03651.x

35. Kim N, Im KI, Lim JY, Jeon EJ, Nam YS, Kim EJ, et al. Mesenchymal stem cells for the treatment and prevention of graft-versus-host disease: experiments and practice. Ann Hematol (2013) 92(10):1295-308. doi:10.1007/ s00277-013-1796-Z

36. Dunavin N, Dias A, Li M, McGuirk J. Mesenchymal stromal cells: what is the mechanism in acute graft-versus-host disease? Biomedicines (2017) 5(3). doi:10.3390/biomedicines5030039

37. Le Blanc K, Rasmusson I, Sundberg B, Götherström C, Seidel C, Sundberg B, et al. Treatment of severe acute graft-versus-host disease with third party haploidentical mesenchymal stem cells. Lancet (2004) 363(9419):1439-41. doi:10.1016/S0140-6736(04)16104-7

38. Muroi K, Miyamura K, Okada M, Yamashita T, Murata M, Ishikawa T, et al. Bone marrow-derived mesenchymal stem cells (JR-031) for steroid-refractory grade III or IV acute graft-versus-host disease: a phase II/III study. Int J Hematol (2016) 103(2):243-50. doi:10.1007/s12185-015-1915-9

39. Introna M, Lucchini G, Dander E, Galimberti S, Rovelli A, Balduzzi A, et al. Treatment of graft versus host disease with mesenchymal stromal cells: a phase I study on 40 adult and pediatric patients. Biol Blood Marrow Transplant (2014) 20(3):375-81. doi:10.1016/j.bbmt.2013.11.033

40. Dotoli GM, De Santis GC, Orellana MD, de Lima Prata K, Caruso SR, Fernandes TR, et al. Mesenchymal stromal cell infusion to treat steroidrefractory acute GvHD III/IV after hematopoietic stem cell transplantation. Bone Marrow Transplant (2017) 52(6):859-62. doi:10.1038/bmt.2017.35

41. Baygan A, Aronsson-Kurttila W, Moretti G, Tibert B, Dahllöf G, Klingspor L, et al. Safety and side effects of using placenta-derived decidual stromal cells for graft-versus-host disease and hemorrhagic cystitis. Front Immunol (2017) 8:795. doi:10.3389/fimmu.2017.00795

42. Jurado M, De La Mata C, Ruiz-García A, López-Fernández E, Espinosa O, Remigia MJ, et al. Adipose tissue-derived mesenchymal stromal cells as part of therapy for chronic graft-versus-host disease: a phase I/II study. Cytotherapy (2017) 19(8):927-36. doi:10.1016/j.jcyt.2017.05.002

43. Tobin LM, Healy ME, English K, Mahon BP. Human mesenchymal stem cells suppress donor CD4(+) $\mathrm{T}$ cell proliferation and reduce pathology in a humanized mouse model of acute graft-versus-host disease. Clin Exp Immunol (2013) 172(2):333-48. doi:10.1111/cei.12056

44. Nazarov C, Lo Surdo J, Bauer SR, Wei CH. Assessment of immunosuppressive activity of human mesenchymal stem cells using murine antigen specific CD4 and CD8 T cells in vitro. Stem Cell Res Ther (2013) 4(5):128. doi:10.1186/ scrt339

45. Li M, Sun X, Kuang X, Liao Y, Li H, Luo D. Mesenchymal stem cells suppress CD8+ $\mathrm{T}$ cell-mediated activation by suppressing natural killer group 2, member D protein receptor expression and secretion of prostaglandin E2, indoleamine 2, 3-dioxygenase and transforming growth factor-beta. Clin Exp Immunol (2014) 178(3):516-24. doi:10.1111/cei.12423

46. Lalu MM, McIntyre L, Pugliese C, Fergusson D, Winston BW, Marshall JC, et al. Safety of cell therapy with mesenchymal stromal cells (SafeCell): a systematic review and meta-analysis of clinical trials. PLoS One (2012) 7(10):e47559. doi:10.1371/journal.pone.0047559 
47. Capelli C, Pedrini O, Cassina G, Spinelli O, Salmoiraghi S, Golay J, et al. Frequent occurrence of non-malignant genetic alterations in clinical grade mesenchymal stromalcells expanded for cell therapy protocols. Haematologica (2014) 99(6):e94-7. doi:10.3324/haematol.2014.104711

48. Barkholt L, Flory E, Jekerle V, Lucas-Samuel S, Ahnert P, Bisset L, et al. Risk of tumorigenicity in mesenchymal stromal cell-based therapies - bridging scientific observations and regulatory viewpoints. Cytotherapy (2013) 15(7): 753-9. doi:10.1016/j.jcyt.2013.03.005

49. Yang D, Wang LP, Zhou H, Cheng H, Bao XC, Xu S, et al. Inducible costimulator gene transduced bone marrow derived mesenchymal stem cells attenuate the severity of acute graft-versus-host disease in mouse models. Cell Transplant (2015) 24(9):1717-31. doi:10.3727/096368914X684592

50. Roncarolo MG, Battaglia M. Regulatory T-cell immunotherapy for tolerance to self antigens and alloantigens in humans. Nat Rev Immunol (2007) 7(8):585-98. doi:10.1038/nri2138

51. Qian L, Wu Z, Shen J. Advances in the treatment of acute graft-versus-host disease. J Cell Mol Med (2013) 17(8):966-75. doi:10.1111/jcmm.12093

52. Zhao S, Zhang L, Han J, Chu J, Wang H, Chen X, et al. Conformal nanoencapsulation of allogeneic $\mathrm{T}$ cells mitigates graft-versus-host disease and retains graft-versus-leukemia activity. ACS Nano (2016) 10(6):6189-200. doi:10.1021/acsnano.6b02206

53. Busca A. The use of monoclonal antibodies for the treatment of graftversus-host disease following allogeneic stem cell transplantation. Expert Opin Biol Ther (2011) 11(6):687-97. doi:10.1517/14712598.2011.566852

54. Hamidieh AA, Hadjibabaie M, Ghehi MT, Jalili M, Hosseini A, Pasha F, et al. Long-term follow-up of children treated with daclizumab for steroidrefractory gastrointestinal GvHD in a prospective study. Pediatr Transplant (2012) 16(6):664-9. doi:10.1111/j.1399-3046.2012.01753.x

55. Miano M, Cuzzubbo D, Terranova P, Giardino S, Lanino E, Morreale G, et al. Daclizumab as useful treatment in refractory acute GVHD: a paediatric experience. Bone Marrow Transplant (2009) 43(5):423-7. doi:10.1038/ bmt.2008.331

56. Rao K, Rao A, Karlsson H, Jagani M, Veys P, Amrolia PJ. Improved survival and preserved antiviral responses after combination therapy with daclizumab and infliximab in steroid-refractory graft-versus-host disease. JPediatr Hematol Oncol (2009) 31(6):456-61. doi:10.1097/MPH.0b013e31819daf60

57. Rager A, Frey N, Goldstein SC, Reshef R, Hexner EO, Loren A, et al. Inflammatory cytokine inhibition with combination daclizumab and infliximab for steroid-refractory aGVHD. Bone Marrow Transplant (2011) 46(3): 430-5. doi:10.1038/bmt.2010.117

58. Arcese W, Picardi A, Santarone S, De Angelis G, Cerretti R, Cudillo L, et al. Haploidentical, G-CSF-primed, unmanipulated bone marrow transplantation for patients with high-risk hematological malignancies: an update. Bone Marrow Transplant (2015) 50(Suppl 2):S24-30. doi:10.1038/bmt.2015.91

59. Fang J, Hu C, Hong M, Wu Q, You Y, Zhong Z, et al. Prophylactic effects of interleukin-2 receptor antagonists against graft-versus-host disease following unrelated donor peripheral blood stem cell transplantation. Biol Blood Marrow Transplant (2012) 18(5):754-62. doi:10.1016/j.bbmt.2011.09.005

60. Piñana JL, Valcárcel D, Martino R, Moreno ME, Sureda A, Briones J, et al. Encouraging results with inolimomab (anti-IL-2 receptor) as treatment for refractory acute graft-versus-host disease. Biol Blood Marrow Transplant (2006) 12(11):1135-41. doi:10.1016/j.bbmt.2006.06.010

61. van Groningen LF, Liefferink AM, de Haan AF, Schaap NP, Donnelly JP, Blijlevens NM, et al. Combination therapy with inolimomab and etanercept for severe steroid-refractory acute graft-versus-host disease. Biol Blood Marrow Transplant (2016) 22(1):179-82. doi:10.1016/j.bbmt.2015.08.039

62. Kennedy-Nasser AA, Ku S, Castillo-Caro P, Hazrat Y, Wu MF, Liu H, et al. Ultra low-dose IL-2 for GVHD prophylaxis after allogeneic hematopoietic stem cell transplantation mediates expansion of regulatory $\mathrm{T}$ cells without diminishing antiviral and antileukemic activity. Clin Cancer Res (2014) 20(8):2215-25. doi:10.1158/1078-0432.CCR-13-3205

63. Couriel DR, Saliba R, de Lima M, Giralt S, Andersson B, Khouri I, et al. A phase III study of infliximab and corticosteroids for the initial treatment of acute graft-versus-host disease. Biol Blood Marrow Transplant (2009) 15:1555-62. doi:10.1016/j.bbmt.2009.08.003

64. Leclerc M, Naserian S, Pilon C, Thiolat A, Martin GH, Pouchy C, et al. Control of GVHD by regulatory T cells depends on TNF produced by T cells and TNFR2 expressed by regulatory T cells. Blood (2016) 128(12):1651-9. doi:10.1182/blood-2016-02-700849
65. Tamura S, Ishida H, Fujiki A, Yoshihara T, Kondo O, Inoue M, et al. Effective infliximab treatment for a recurrent type of acute intestinal graft-versus-host disease accompanied by steroid-induced depression. Rinsho Ketsueki (2012) 53(3):361-6.

66. Choi SW, Stiff P, Cooke K, Ferrara JL, Braun T, Kitko C, et al. TNF-inhibition with etanercept for graft-versus-host disease prevention in high-risk HCT: lower TNFR1 levels correlate with better outcomes. Biol Blood Marrow Transplant (2012) 18(10):1525-32. doi:10.1016/j.bbmt.2012.03.013

67. Busca A, Locatelli F, Marmont F, Ceretto C, Falda M. Recombinant human soluble tumor necrosis factor receptor fusion protein as treatment for steroid refractory graft-versus-host disease following allogeneic hematopoietic stem cell transplantation. Am J Hematol (2007) 82(1):45-52. doi:10.1002/ajh.20752

68. Gatza E, Braun T, Levine JE, Ferrara JL, Zhao S, Wang T, et al. Etanercept plus topical corticosteroids as initial therapy for grade one acute graft-versus-host disease after allogeneic hematopoietic cell transplantation. Biol Blood Marrow Transplant (2014) 20(9):1426-34. doi:10.1016/j.bbmt.2014.05.023

69. Park JH, Lee HJ, Kim SR, Song GW, Lee SK, Park SY, et al. Etanercept for steroid-refractory acute graft versus host disease following allogeneic hematopoietic stem cell transplantation. Korean J Intern Med (2014) 29(5):630-6. doi:10.3904/kjim.2014.29.5.630

70. Prazma CM, Tedder TF. Dendritic cell CD83: a therapeutic target or innocent bystander? Immunol Lett (2008) 115(1):1-8. doi:10.1016/j.imlet.2007.10.001

71. Ge W, Arp J, Lian D, Liu W, Baroja ML, Jiang J, et al. Immunosuppression involving soluble CD83 induces tolerogenic dendritic cells that prevent cardiac allograft rejection. Transplantation (2010) 90(11):1145-56. doi:10.1097/ TP.0b013e3181f95718

72. Lan Z, Ge W, Arp J, Jiang J, Liu W, Gordon D, et al. Induction of kidney allograft tolerance by soluble CD83 associated with prevalence of tolerogenic dendritic cells and indoleamine 2,3-dioxygenase. Transplantation (2010) 90(12):1286-93. doi:10.1097/TP.0b013e3182007bbf

73. Wilson J, Cullup H, Lourie R, Sheng Y, Palkova A, Radford KJ, et al. Antibody to the dendritic cell surface activation antigen CD83 prevents acute graftversus-host disease. J Exp Med (2009) 206(2):387-98. doi:10.1084/jem.20070723

74. Wang X, Wei MQ, Liu X. Targeting CD83 for the treatment of graft-versushost disease. Exp Ther Med (2013) 5(6):1545-50. doi:10.3892/etm.2013.1033

75. Cutler C, Miklos D, Kim HT, Treister N, Woo SB, Bienfang D, et al. Rituximab for steroid-refractory chronic graft-versus-host disease. Blood (2006) 108(2): 756-62. doi:10.1182/blood-2006-01-0233

76. Kharfan-Dabaja MA, Mhaskar AR, Djulbegovic B, Cutler C, Mohty M, Kumar A. Efficacy of rituximab in the setting of steroid-refractory chronic graft-versus-host disease: a systematic review and meta-analysis. Biol Blood Marrow Transplant (2009) 15(9):1005-13. doi:10.1016/j.bbmt.2009.04.003

77. Johnston HF, Xu Y, Racine JJ, Cassady K, Ni X, Wu T, et al. Administration of anti-CD20 mAb is highly effective in preventing but ineffective in treating chronic graft-versus-host disease while preserving strong graftversus-leukemia effects. Biol Blood Marrow Transplant (2014) 20(8):1089-103. doi:10.1016/j.bbmt.2014.04.028

78. Hechinger AK, Smith BA, Flynn R, Hanke K, McDonald-Hyman C, Taylor PA, et al. Therapeutic activity of multiple common gamma-chain cytokine inhibition in acute and chronic GVHD. Blood (2015) 125(3):570-80. doi:10.1182/ blood-2014-06-581793

79. Picarda E, Bézie S, Boucault L, Autrusseau E, Kilens S, Meistermann D, et al. Transient antibody targeting of CD45RC induces transplant tolerance and potent antigen-specific regulatory T cells. JCI Insight (2017) 2(3):e90088. doi:10.1172/jci.insight.90088

80. Yu XZ, Albert MH, Martin PJ, Anasetti C. CD28 ligation induces transplantation tolerance by IFN-gamma-dependent depletion of T cells that recognize alloantigens. J Clin Invest (2004) 113(11):1624-30. doi:10.1172/JCI20940

81. Poirier N, Mary C, Dilek N, Hervouet J, Minault D, Blancho G, et al. Preclinical efficacy and immunological safety of FR104, an antagonist anti-CD28 monovalent Fab' antibody. Am J Transplant (2012) 12(10):2630-40. doi:10.1111/j. 1600-6143.2012.04164.x

82. Tran IT, Sandy AR, Carulli AJ, Ebens C, Chung J, Shan GT, et al. Blockade of individual Notch ligands and receptors controls graft-versus-host disease. J Clin Invest (2013) 123(4):1590-604. doi:10.1172/JCI65477

83. Sandy AR, Chung J, Toubai T, Shan GT, Tran IT, Friedman A, et al. T cellspecific notch inhibition blocks graft-versus-host disease by inducing a hyporesponsive program in alloreactive CD4+ and CD8+ T cells. J Immunol (2013) 190(11):5818-28. doi:10.4049/jimmunol.1203452 
84. Shono Y, Tuckett AZ, Ouk S, Liou HC, Altan-Bonnet G, Tsai JJ, et al. A small-molecule c-Rel inhibitor reduces alloactivation of $\mathrm{T}$ cells without compromising antitumor activity. Cancer Discov (2014) 4(5):578-91. doi:10.1158/2159-8290.CD-13-0585

85. Shono Y, Tuckett AZ, Liou HC, Doubrovina E, Derenzini E, Ouk S, et al. Characterization of a c-Rel inhibitor that mediates anticancer properties in hematologic malignancies by blocking NF- $\mathrm{BB}$-controlled oxidative stress responses. CancerRes (2016) 76(2):377-89. doi:10.1158/0008-5472.CAN-14-2814

86. Le Huu D, Kimura H, Date M, Hamaguchi Y, Hasegawa M, Hau KT, et al. Blockade of Syk ameliorates the development of murine sclerodermatous chronic graft-versus-host disease. J Dermatol Sci (2013) 74(3):214-21. doi:10.1016/ j.jdermsci.2014.02.008

87. Flynn R, Paz K, Du J, Reichenbach DK, Taylor PA, Panoskaltsis-Mortari A, et al. Targeted Rho-associated kinase 2 inhibition suppresses murine and human chronic GVHD through aStat3-dependent mechanism. Blood (2016) 127(17):2144-54. doi:10.1182/blood-2015-10-678706

88. Lee SH, Moon SJ, Park MJ, Kim EK, Moon YM, Cho ML. PIAS3 suppresses acute graft-versus-host disease by modulating effector $\mathrm{T}$ and $\mathrm{B}$ cell subsets through inhibition of STAT3 activation. Immunol Lett (2014) 160(1):79-88. doi:10.1016/j.imlet.2014.03.014

89. Spoerl S, Mathew NR, Bscheider M, Schmitt-Graeff A, Chen S, Mueller T, et al. Activity of therapeutic JAK 1/2 blockade in graft-versus-host disease. Blood (2014) 123(24):3832-42. doi:10.1182/blood-2013-12-543736
90. Maffini E, Giaccone L, Festuccia M, Brunello L, Buondonno I, Ferrero D, et al. Ruxolitinib in steroid refractory graft-vs-host disease: a case report. J Hematol Oncol (2016) 9(1):67. doi:10.1186/s13045-016-0298-6

91. Zeiser R, Burchert A, Lengerke C, Verbeek M, Maas-Bauer K, Metzelder SK, et al. Ruxolitinib in corticosteroid-refractory graft-versus-host disease after allogeneic stem cell transplantation: a multicenter survey. Leukemia (2015) 29(10):2062-8. doi:10.1038/leu.2015.212

92. Khandelwal P, Teusink-Cross A, Davies SM, Nelson AS, Dandoy CE, El-Bietar J, et al. Ruxolitinib as salvage therapy in steroid-refractory acute graft-versus-host disease in pediatric hematopoietic stem cell transplant patients. Biol Blood Marrow Transplant (2017) 23(7):1122-7. doi:10.1016/j. bbmt.2017.03.029

Conflict of Interest Statement: The authors declare that the research was conducted in the absence of any commercial or financial relationships that could be construed as a potential conflict of interest.

Copyright $(2018$ Zhang, Yu and Wei. This is an open-access article distributed under the terms of the Creative Commons Attribution License (CC BY). The use, distribution or reproduction in other forums is permitted, provided the original author(s) and the copyright owner are credited and that the original publication in this journal is cited, in accordance with accepted academic practice. No use, distribution or reproduction is permitted which does not comply with these terms. 